\title{
Potensi Hakisan Tanih di Lembangan Sungai Bilut, Raub, Pahang menggunakan Integrasi RUSLE dan GIS
}

(Soil Erosion Potential at Sungai Bilut Catchment, Raub, Pahang using Integration of RUSLE and GIS)

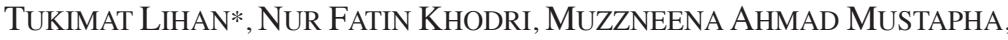 \\ ZULFAHMI ALI RAHMAN \& WAN MOHD RAZI IDRIS
}

\begin{abstract}
ABSTRAK
Aktiviti guna tanah di kawasan lembangan adalah salah satu faktor yang mendorong kepada kemerosotan kualiti air sungai akibat daripada hakisan tanih. Potensi hakisan tanih di kawasan lembangan Sungai Bilut, Raub, Pahang yang menjadi sumber bekalan air minuman utama di daerah Raub boleh ditentukan dengan menggunakan integrasi model Semakan Semula Persamaan Kehilangan Tanih Universal (RUSLE) dan Sistem Maklumat Geografi (GIS). Kajian ini bertujuan untuk menentukan potensi hakisan tanih dan faktor utama yang mempengaruhi kadar hakisan tanih. Kajian ini melibatkan penggunaan data sekunder yang terdiri daripada data hujan, data siri tanih dan topografi bagi menghasilkan faktor kehakisan hujan $(R)$, kebolehhakisan tanih $(K)$, serta panjang dan kecuraman cerun (LS). Faktor litupan tumbuhan $(C)$ dan amalan pemuliharaan $(P)$ pula dijana daripada imej satelit Landsat 8 (2014). Keputusan kajian menunjukkan

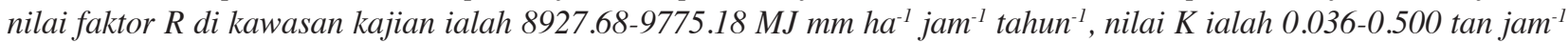
$M^{-1} \mathrm{~mm}^{-1}$, nilai LS ialah 0-514, nilai C ialah 0.03-0.80 dan nilai P ialah 0.1-0.7. Kawasan yang mempunyai potensi hakisan sangat rendah hingga rendah meliputi $81 \%$, manakala potensi hakisan tanih sederhana hingga sangat tinggi meliputi 19\% daripada keseluruhan kawasan kajian. Model yang dihasilkan mempunyai ketepatan sebanyak 81\%. Faktor utama yang mempengaruhi berlakunya hakisan tanih di kawasan kajian adalah faktor topografi, litupan tumbuhan dan kebolehhakisan tanih. Keputusan menunjukkan analisis integrasi RUSLE dan GIS berpotensi dalam penentuan potensi hakisan tanih untuk kawasan luas yang mempunyai pelbagai jenis guna tanah, topografi dan jenis tanih.
\end{abstract}

Kata kunci: GIS; hakisan tanih; RUSLE

\section{ABSTRACT}

Land use activities within catchment area are one of the factors contributing to deterioration of river water quality due to soil erosion. Potential soil erosion at the Sungai Bilut catchment, which is the main source of water supply in Raub district, can be determined using Revised Universal Soil Loss Equation (RUSLE) and Geographical Information System (GIS). The aims of this research were to determine the potential soil loss and also to determine the main factors that influence the rate of soil erosion. This study involved analysis of secondary data of rainfall, soil series and topography data to generate factors of rainfall erosivity $(R)$, soil erodibility $(K)$ and length and steepness of slope $(L S)$. Vegetation coverage and conservation practices factors were generated from satellite image of Landsat 8 (2014). The results showed

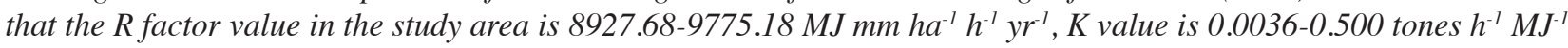
$\mathrm{mm}^{-1}$, LS value is 0-514, C value is 0.03-0.80 and $P$ value is 0.1-0.7. The area that has very low to low erosion potential is $81 \%$, while medium to very high erosion potential is $19 \%$ of total study area. The model has an accuracy of $81 \%$. The main factors that contribute to the potential of soil erosion in the study area are topography, vegetation cover, and soil erodibility. The results indicated the potential of integration of RUSLE and GIS analysis in determination of potential soil erosion in wide area consisting of various land use, topography and soil type.

Keywords: GIS; RUSLE; soil erosion

\section{PENGENALAN}

Hakisan tanih merupakan masalah utama yang dihadapi oleh negara yang mempunyai iklim tropika seperti Malaysia kerana iklim khatulistiwa yang dialami Malaysia menyumbang kepada taburan hujan yang tinggi dengan purata $2400 \mathrm{~mm}$ setahun (Jaafar et al. 2011). Selain itu, kebanyakan kawasan tanah tinggi di negara yang beriklim tropika mengalami kehilangan tanih yang agak teruk disebabkan oleh faktor semula jadi (Markose \& Jayappa 2016). Tanih yang terhakis dari kawasan tinggi adalah punca berlakunya pengurangan kesuburan tanih, mengubah morfologi sungai dan masalah pemendapan (Millward \& Mersey 1999). Hakisan tanih juga memberi kesan kepada bahagian hulu dan hilir sungai. Di hulu sungai, hakisan tanih menyebabkan kehilangan produktiviti dan kehilangan kapasiti penyimpanan air di lokasi terhakis. 
Hasil pemendapan di hilir sungai pula menyebabkan kerosakan kepada kawasan hilir, saluran sungai dan infrastruktur seperti empangan, sistem pengairan dan saliran, sekaligus menyebabkan peningkatan kos kepada pengguna dan menjejaskan kualiti air (Mahmud et al.2015; Terrence et al. 2002).

Kualiti air di kawasan tadahan air di Malaysia bergantung kepada pembangunan di kawasan tinggi, hakisan tanih serta pemendapan. Pembangunan yang pesat di kawasan berbukit sejak tahun 1970-an telah menyebabkan kemusnahan dan kemerosotan kawasan tadahan air, risiko hakisan tanih, peningkatan insiden tanah runtuh dan masalah enapan sedimen (Ibrahim et al. 2002).

Kaedah penentuan hakisan tanih secara konvensional dan kaedah penderiaan jauh serta sistem maklumat geografi (GIS) boleh digunakan sebagai pendekatan bersepadu yang membolehkan anggaran hakisan tanih menjadi lebih mudah, cepat dan kos lebih efektif (Drzewiecki et al. 2013; Qing et al. 2007). Penambahbaikan dan kemajuan dalam teknik penderiaan jauh (RS) dan GIS menjadikannya kaedah yang sesuai untuk menentukan potensi hakisan tanih (Millward \& Mersey 1999). Oleh itu, model RUSLEGIS adalah kaedah yang sesuai dan berkesan untuk menilai dan menganggar risiko hakisan tanah di kawasan kajian. Kajian ini dijalankan di kawasan lembangan Sungai
Bilut, Raub, Pahang dengan keluasan 39518 hektar pada ketinggian di antara $9 \mathrm{~m}$ yang terletak di kawasan hilir hingga $1385 \mathrm{~m}$ dari aras laut di kawasan hulu sungai. Kawasan kajian terletak pada latitud $3^{\circ} 44^{\prime} 17.68^{\prime \prime} \mathrm{U}$ - 3०41'34.89',U dan longitud 101 ${ }^{\circ} 54^{\prime} 22.54$ '' $\mathrm{T}$ $101^{\circ} 56$ '37.15”'T (Rajah 1). Sungai Bilut merupakan sungai yang membekalkan sumber air minuman utama di daerah Raub dan kawasan sekitarnya. Lembangan sungai ini merupakan kawasan tanah tinggi dan bercerun di kawasan hulu serta menerima curahan hujan yang tinggi berpotensi mengalami hakisan yang tinggi. Hakisan yang tinggi boleh menyebabkan kualiti air Sungai Bilut merosot dan seterusnya mempengaruhi proses perawatan air minuman di loji rawatan air. Lembangan Sungai Bilut didominasi oleh guna tanah hutan, tanah lapang, pertanian serta guna tanah bandar. Kepelbagaian guna tanah, topografi dan jenis tanih di kawasan kajian memerlukan kaeadah yang sesuai untuk mengkaji kadar hakisan dengan lebih menyeluruh. Kajian ini melibatkan integrasi RUSLE dan GIS untuk menganggarkan kehilangan tanih dan mengenal pasti kawasan yang berisiko hakisan dalam kawasan kajian untuk menilai kesahihan model hakisan tanih secara reruang (Millward \& Mersey 1999; Muhammad Rendana et al. 2017). Objektif kajian ini adalah untuk menentukan potensi hakisan tanih serta menentukan faktor utama yang

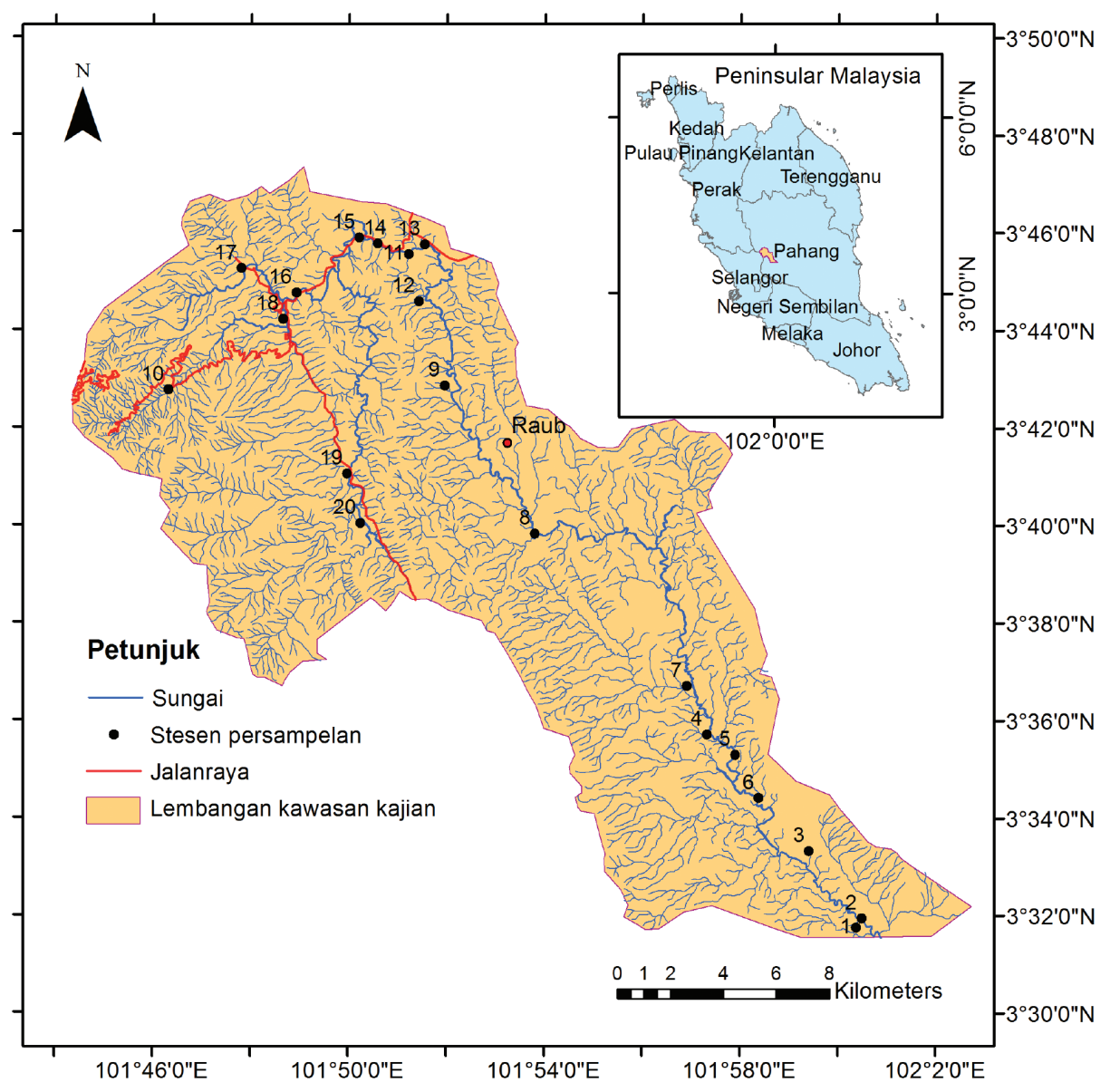

RAJAH 1. Kawasan kajian menunjukkan Sungai Bilut dan anak sungai serta stesen persampelan di lembangan Sungai Bilut 
mempengaruhi kadar hakisan tanih di lembangan Sungai Bilut, Raub, Pahang.

\section{BAHAN DAN KAEDAH}

Kajian penentuan hakisan tanih (A) menggunakan model RUSLE dalam sekitaran ArcGIS 10.2 untuk menghasilkan lapisan faktor kehakisan hujan (R), kebolehhakisan tanih (K), panjang dan kecerunan cerun (LS), litupan tumbuhan (C) dan amalan pemuliharaan $(\mathrm{P})$. Potensi hakisan tanih (A) di lapangan juga dilakukan menggunakan nilai faktor kehakisan hujan (R), kebolehhakisan tanih (K), topografi (LS), litupan tumbuhan (C) dan amalan pemuliharaan (P) yang digunakan sebagai penentusahan. Secara amnya, pendekatan keseluruhan kajian ini ditunjukkan di dalam Rajah 2.

Permodelan menggunakan RUSLE adalah bertujuan untuk menganggarkan purata kehilangan tanih yang diakibatkan oleh percikan hujan, hakisan permukaan dan hakisan alur di kawasan lembangan Sungai Bilut, Raub, Pahang. Persamaan RUSLE adalah seperti berikut (Renard et al. 1997):

$$
\mathrm{A}=\text { R.K.LS.C.P }
$$

dengan A ialah keseluruhan kehilangan tanih per unit kawasan $\left(\tan \mathrm{ha}^{-1} \operatorname{tahun}^{-1}\right)$; R ialah faktor kehakisan hujan (MJ mm ha ${ }^{-1}$ jam $^{-1}$ tahun $\left.^{-1}\right)$; K ialah faktor kebolehhakisan tanih ( $\tan$ jam $\mathrm{MJ}^{-1} \mathrm{~mm}^{-1}$ ); LS ialah faktor panjang dan kecuraman cerun; $\mathrm{C}$ ialah faktor litupan tumbuhan; dan $\mathrm{P}$ ialah faktor amalan pemuliharaan.

\section{FAKTOR KEHAKISAN HUJAN (R)}

kehakisan hujan ditentukan berdasarkan data hujan bulanan dari tahun 2011 hingga Ogos 2014 bagi 5 stesen pencerapan telah diperoleh daripada Jabatan Meteorologi Malaysia bagi menentukan nilai purata hujan tahunan di kawasan kajian. Stesen pencerapan yang terlibat adalah Felda Jenderak Utara, Felda Tersang Satu, Pos Sungai Dua, Pusat Pertanian Batang Kali dan Telekom Bukit Peninjau. Penganggaran taburan hujan di seluruh kawasan kajian dilakukan dengan menggunakan kaedah interpolasi Inverse Distance Weighted (IDW). Faktor kehakisan hujan ditentukan dengan menggunakan nilai purata hujan tahunan melalui rumus Morgan (2005).

$$
\mathrm{R}=(9.28 \mathrm{P}-8838.15 \times 75) / 100
$$

dengan P ialah Purata hujan tahunan (mm); R ialah indeks kehakisan hujan ( $\mathrm{MJ} \mathrm{mm} \mathrm{ha}^{-1} \mathrm{jam}^{-1}$ tahun $\left.^{-1}\right)$.

\section{FAKTOR KEBOLEHHAKISAN TANIH (K)}

Penentuan faktor kebolehhakisan tanih dilakukan menggunakan peta tanih yang diperoleh daripada Jabatan Pertanian Malaysia. Nilai kebolehhakisan tanih (K) yang digunakan berdasarkan nilai faktor $\mathrm{K}$ mengikut siri tanih yang disarankan oleh Kementerian Sumber Asli dan Alam Sekitar (2010) (Jadual 1).

\section{FAKTOR PANJANG DAN KECURAMAN CERUN (LS)}

Faktor LS telah ditentukan menggunakan peta kontur yang diperoleh daripada Jabatan Ukur dan Pemetaan Malaysia

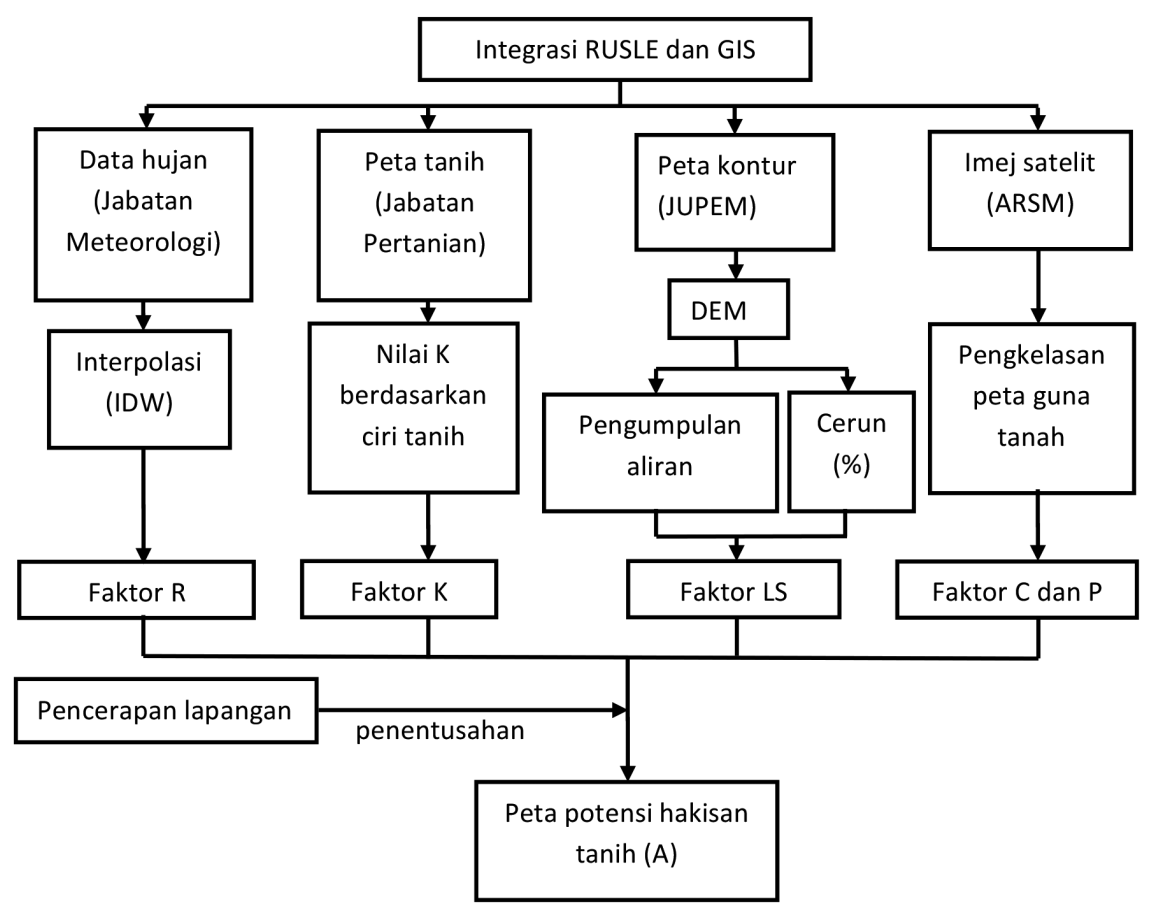

RAJAH 2. Carta alir pendekatan kajian bagi penentuan potensi hakisan tanih 
JADUAL 1. Nilai K berdasarkan siri tanih di kawasan kajian

\begin{tabular}{cllc}
\hline No & Siri Tanih & Tekstur tanih & Nilai K \\
\hline 1 & Telemong Akob Lanar Tempatan & lempung & 0.036 \\
2 & Kelau Kawang & Lempung berlodak & 0.043 \\
3 & Batu Anam Durian & Lempung berlodak & 0.098 \\
4 & Serdang Bungor Munchong & Lom lempung berpasir & 0.102 \\
5 & Rengam Jerangau & Lempung berpasir & 0.109 \\
6 & Durian Munchong Bungor & Lempung berpasir halus & 0.114 \\
7 & Serdang Kedah & Lom Lempung berpasir & 0.128 \\
8 & Tanah Curam & Lom berpasir & 0.500 \\
\hline
\end{tabular}

Sumber: Kementerian Sumber Asli dan Alam Sekitar (2010)

(JUPEM). Kaedah Model Ketinggian Berdigit atau Digital Elevation Model (DEM) yang dihasilkan menggunakan peta kontur digunakan untuk menghasilkan peta cerun (Mohamad et al. 2010). Seterusnya, faktor LS ditentukan menggunakan persamaan oleh Wischmeier dan Smith (1978),

$$
\begin{aligned}
\mathrm{LS}= & {[(\text { Pengumpulan aliran } \times \text { nilai sel } / 22.1)]^{\mathrm{m}} } \\
& \left(0.065+0.045 \mathrm{~S}+0.0065 \mathrm{~S}^{2}\right)
\end{aligned}
$$

dengan S ialah kecuraman cerun (\%); dan m ialah indeks kecerunan (Jadual 2).

JADUAL 2. Nilai indeks kecerunan (m) bagi faktor LS

\begin{tabular}{cc}
\hline Nilai m & Kecuraman cerun $(\%)$ \\
\hline 0.50 & $>5$ \\
0.40 & $3-5$ \\
0.30 & $1-3$ \\
0.20 & $<1$ \\
\hline
\end{tabular}

Sumber: Wischmeier and Smith 1978

\section{FAKTOR LITUPAN TUMBUHAN (C) DAN AMALAN PEMULIHARAAN (P)}

Faktor $\mathrm{C}$ dan $\mathrm{P}$ ditentukan berdasarkan peta guna tanah daripada imej Landsat 8 (2014) melalui proses pengkelasan tak berselia. Dalam kajian ini, pengkelasan tak berselia menggunakan algorithma ISODATA (Iterative SelfOrganizing Data Analysis Technique) dijalankan untuk menghasilkan 4 jenis guna tanah (Hamid et al. 2017). Empat jenis guna tanah yang dihasilkan adalah bandar, tanah lapang, pertanian dan hutan. Nilai faktor C (Jadual 3) dan P (Jadual 4) yang digunakan dalam kajian ini berdasarkan kajian yang dilakukan oleh Jabatan Pengairan dan Saliran (2010) dan Troeh et al. (1999).

\section{PENGUKURAN DI LAPANGAN}

Faktor hakisan yang terdiri daripada panjang dan kecerunan cerun, jenis guna tanah dan amalan pemuliharan telah diukur di lapangan pada setiap titik koordinat stesen persampelan. Faktor kehakisan dianalisis melalui rumus Morgan (2005) menggunakan data hujan bulanan daripada Jabatan Meteorologi Malaysia. Sampel tanih juga diambil
JADUAL 3. Nilai faktor litupan tumbuhan (C) berdasarkan jenis tumbuhan penutup

\begin{tabular}{lc}
\multicolumn{1}{c}{ Tumbuh-tumbuhan penutup } & $\begin{array}{c}\text { Nilai } \\
\text { faktor C }\end{array}$ \\
\hline Kawasan ragut & 0.23 \\
Hutan/pokok & \\
Litupan tumbuhan 25\% & 0.42 \\
Litupan tumbuhan 50\% & 0.39 \\
Litupan tumbuhan 75\% & 0.36 \\
Litupan tumbuhan 100\% & 0.03 \\
Semak/pokok renek & \\
Litupan tumbuhan 25\% & 0.40 \\
Litupan tumbuhan 50\% & 0.35 \\
Litupan tumbuhan 75\% & 0.30 \\
Litupan tumbuhan 100\% & 0.03 \\
Badan air & 0.01 \\
Hortikultur & 0.25 \\
Pokok kelapa sawit & 0.20 \\
Pokok getah & 0.20 \\
Kawasan kediaman & \\
Kepadatan rendah (50\% kawasan hijau) & 0.25 \\
Kepadatan sederhana (25\% kawasan hijau) & 0.15 \\
Kepadatan tinggi (5\% kawasan hijau) & 0.05 \\
Kawasan terbuka/ kawasan baru & 1.00 \\
\hline
\end{tabular}

Sumber: Jabatan Pengairan dan Saliran (2010)

JADUAL 4. Nilai faktor amalan pemuliharaan $(\mathrm{P})$ berdasarkan jenis guna tanah

\begin{tabular}{lc}
\hline Jenis guna tanah & Nilai faktor P \\
\hline Hutan & 0.10 \\
Hortikultur bercampur & 0.40 \\
Kebun & 0.40 \\
Getah & 0.40 \\
Tanah lapang & 0.70 \\
Tanah baru dibuka & 0.70 \\
Kawasan Bandar & 1.00 \\
\hline
\end{tabular}

Sumber: Troeh et al. (1999)

untuk analisis taburan saiz partikel, bahan organik tanih dan konduktiviti hidraulik. Saiz partikel ditentukan menggunakan kaedah pipet (Abdulla 1966), bahan organik tanih menggunakan kaedah gravimetrik (Avery \& Bascomb 1982) dan konduktiviti hidraulik menggunakan 
kaedah falling head (Kirkby 1980). Kadar hakisan tanih di lapangan juga ditentukan menggunakan model RUSLE.

\section{KEPUTUSAN}

Parameter RUSLE iaitu kehakisan hujan, kebolehhakisan tanih, panjang dan kecuraman cerun, litupan tumbuhan dan amalan pemuliharaan sangat berkait rapat antara satu sama lain (Rajah 3). Lima stesen pencerapan hujan menunjukkan julat purata hujan tahunan antara 2235.1 hingga $2444.5 \mathrm{~mm} /$ tahun. Hasil analisis taburan hujan menunjukkan nilai kehakisan hujan yang paling tinggi adalah di Pusat Pertanian Batang Kali (10385.3 MJ mm ha $^{-1}$ jam $^{-1}$ tahun $^{-1}$ ) manakala paling rendah adalah di Telekom Bukit Peninjau (8927.7 MJ mm ha ${ }^{-1}$ jam $^{-1}$ tahun $^{-1}$ ). Nilai kehakisan didapati tinggi di bahagian tenggara kawasan kajian dan semakin rendah apabila menganjur ke barat laut (Rajah 3A).

Data DEM yang meliputi kawasan kajian menunjukkan kawasan yang paling tinggi adalah pada $1385 \mathrm{~m}$ yang meliputi kawasan hulu sungai di barat laut manakala paling rendah pada $9 \mathrm{~m}$ dari aras laut di kawasan hilir sungai di tenggara kawasan kajian. Nilai LS dikelaskan (Rajah 3B) berdasarkan kajian yang telah dilakukan Kamaludin et al. (2013) di lembangan Sungai Pahang. Keputusan kajian menunjukkan faktor LS yang kurang daripada 5 adalah sebanyak 87\% (34311 hektar) manakala nilai LS yang melebihi 5 adalah sebanyak $13 \%$ (5196 hektar) (Jadual 5). Keputusan kajian menunjukkan terdapat 8 siri tanih iaitu Telemong Akob Lanar Tempatan, Kelau Kawang, Batu Anam Durian, Serdang Bungor Munchong, Rengam Jerangau, Durian Munchong Bungor, Serdang Kedah dan Tanah Curam mempunyai nilai $\mathrm{K}$ yang berbeza di kawasan kajian. Julat nilai kebolehhakisan tanih di kawasan kajian adalah 0.036 hingga 0.500 tan $\mathrm{jam}^{-1} \mathrm{MJ}^{-1} \mathrm{~mm}^{-1}$. Sebahagian besar kawasan kajian mempunyai tanih daripada siri Tanah Curam dan Serdang Kedah iaitu 45\% (18041 hektar) dan $31 \%$ (12396 hektar). Siri tanih Serdang Bungor Munchong pula merupakan siri ketiga terbanyak di kawasan kajian iatu 14\% (5643 hektar). Manakala siri tanih yang mempunyai nilai kebolehhakisan terendah di kawasan kajian adalah daripada siri tanih Batu Anam Durian iaitu sebanyak 0.3\% (114 hektar) (Rajah 3C).

Peta guna tanah hasil daripada pengkelasan tak berselia imej Landsat 8 telah digunakan bagi menghasilkan lapisan faktor $\mathrm{P}$ dan $\mathrm{C}$. Terdapat 4 jenis guna tanah yang dominan di kawasan kajian, iaitu hutan, tanah lapang, Pertanian dan bandar (Rajah 3D dan 3E). Setiap jenis guna tanah mempunyai nilai $\mathrm{C}$ dan $\mathrm{P}$ yang berbeza. Sebahagian besar kawasan kajian terdiri daripada guna tanah hutan yang meliputi $66 \%$ dan diikuti oleh guna tanah jenis tanah lapang $(23 \%)$, pertanian $(10 \%)$ dan bandar $(1 \%)$.

Peta potensi hakisan tanih (A) yang dihasilkan adalah melalui proses tindan lapis faktor RUSLE iaitu kehakisan hujan (R), kebolehhakisan tanih (K), topografi (LS), litupan tumbuhan $(\mathrm{C})$ dan amalan pemuliharaan $(\mathrm{P})$. Peta hakisan tanih dikelaskan kepada 5 kelas berdasarkan Jabatan
Pengairan dan Saliran (2010) iaitu sangat rendah $(<10$ $\left.\tan \mathrm{ha}^{-1} \mathrm{th}^{-1}\right)$, rendah (10.1-50 tan ha $\left.\mathrm{h}^{-1} \mathrm{th}^{-1}\right)$, sederhana (50.1$\left.100 \tan \mathrm{ha}^{-1} \mathrm{th}^{-1}\right)$, tinggi (100.1-150 tan $\left.\mathrm{ha}^{-1} \mathrm{th}^{-1}\right)$ dan sangat tinggi ( $>150$ tan $\left.\mathrm{ha}^{-1} \mathrm{th}^{-1}\right)$. Keputusan kajian menunjukkan bahawa kelas potensi hakisan di kawasan kajian meliputi kelas sangat rendah iaitu seluas 29060 hektar (74\%), kelas potensi hakisan rendah seluas 2923 hektar (7\%), kelas sederhana seluas 1432 hektar (4\%), kelas tinggi seluas 5145 hektar $(13 \%)$ dan sangat tinggi seluas 857 hektar (2\%) yang tertabur di sekitar kawasan kajian (Rajah 4).

\section{PERBINCANGAN}

Malaysia adalah negara beriklim khatulistiwa yang menerima jumlah hujan tahunan yang tinggi. Oleh yang demikian, tanih yang terletak pada kawasan garisan khatulistiwa lebih mudah mengalami hakisan disebabkan oleh air. Faktor air yang menyumbang berlakunya hakisan adalah disebabkan oleh intensiti hujan, tempoh hujan, halaju dan bentuk titisan hujan serta tenaga kinetik hujan (Kementerian Sumber Asli dan Alam Sekitar 2010). Keputusan kajian menunjukkan kawasan yang mempunyai kehakisan hujan yang tinggi mempunyai potensi hakisan yang tinggi. Walau bagaimanapun, terdapat kawasan yang mempunyai kehakisan hujan yang rendah turut berpotensi hakisan tanih yang tinggi (barat laut kawasan kajian). Ini menunjukkan bahawa faktor kehakisan hujan kurang mempengaruhi hakisan tanih di kawasan kajian $(r=0.23)$ dan faktor lain adalah lebih mempengaruhi hakisan seperti kebolehhakisan tanih (K), topografi (LS), litupan tumbuhan (C) dan amalan pemuliharaan $(\mathrm{P})$.

Keadaan fizikal tanih di sesuatu kawasan juga memainkan peranan yang penting dalam proses hakisan. Faktor yang diambil kira dalam kebolehakisan tanih adalah berkaitan dengan saiz agregat, kestabilan struktur dan ketelapan tanih (Troeh et al. 1991). Kajian lapangan menunjukkan peratusan komponen pasir di semua lokasi persampelan berada dalam lingkungan $21 \%$ hingga $76 \%$. Tanih yang mempunyai peratus pasir yang tinggi adalah kurang terdedah kepada pemisahan tanih dan hakisan kerana mempunyai kadar penyusupan yang tinggi (Panagos et al. 2014). Terdapat juga lokasi kajian yang mencatatkan peratus lempung yang tinggi iaitu $42 \%$. Berdasarkan kepada NRCS-USDA (2002), tanih yang mempunyai peratus lempung yang tinggi mempunyai nilai $\mathrm{K}$ yang rendah dan nilainya adalah berada dalam lingkungan 0.05 sehingga 0.15 . Tanih jenis ini lebih tahan daripada hakisan. Tekstur tanih seperti lodak berlempung mempunyai nilai $\mathrm{K}$ yang sederhana dengan nilai antara 0.25 sehingga 0.40 . Tanih yang mempunyai peratus lodak yang tinggi mempunyai nilai $\mathrm{K}$ yang tinggi iaitu nilai $\mathrm{K}$ melebihi 0.40. Tanih jenis ini akan lebih mudah terhakis. Menurut Morgan (2005), tanih yang mempunyai 40\% lodak mempunyai nilai kebolehhakisan yang tinggi, manakala tanih yang mempunyai peratus lempung antara 9\% sehingga $30 \%$ lebih tahan kepada hakisan. Tanah yang mengandungi kandungan lempung yang tinggi mempunyai 

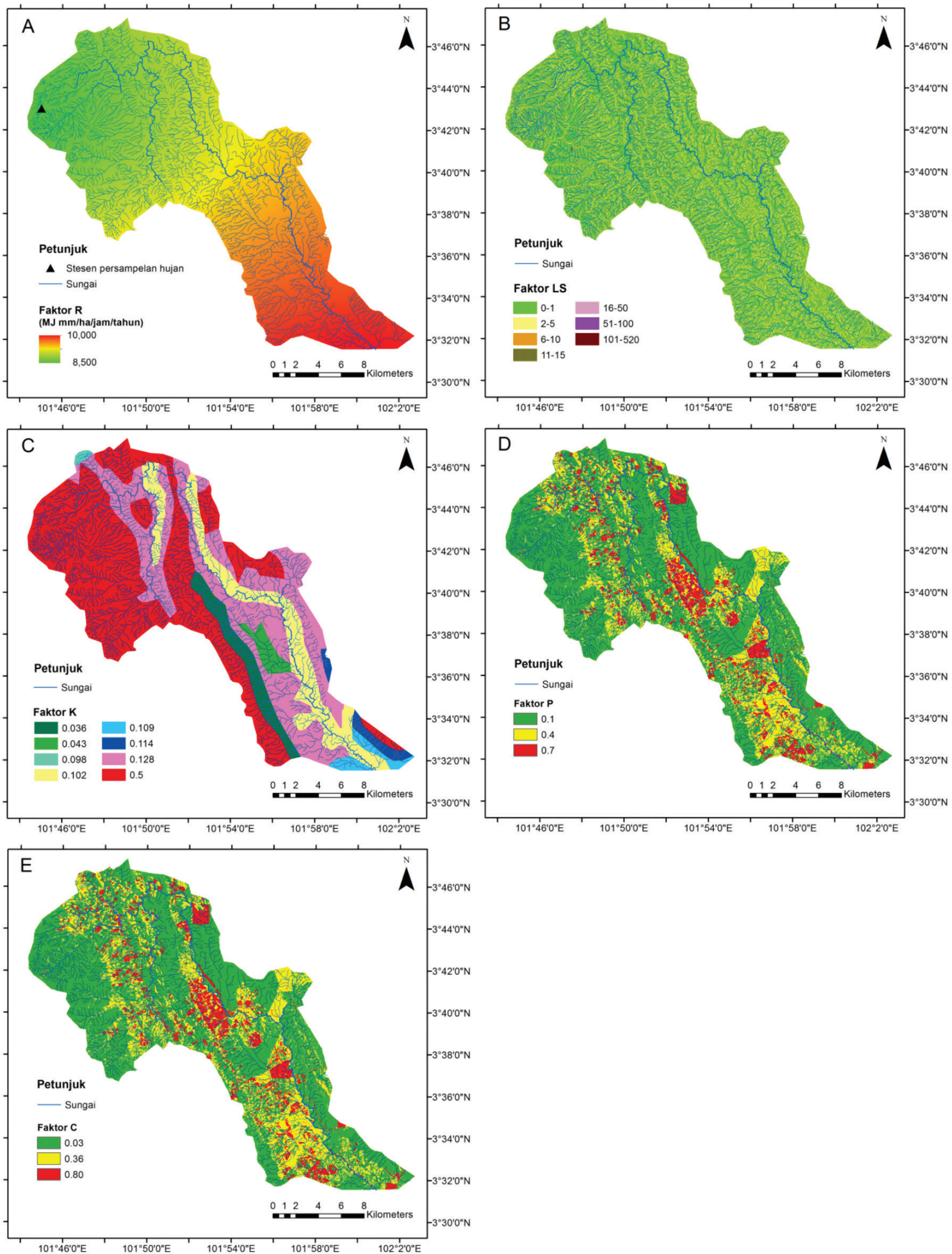

RAJAH 3. A) Lapisan faktor kehakisan hujan (R), B) faktor panjang dan kecuraman cerun (LS), C) faktor kebolehhakisan tanih $(\mathrm{K})$, D) faktor amalan pemuliharaan (P) dan E) faktor litupan tumbuhan (C) di lembangan Sungai Bilut 


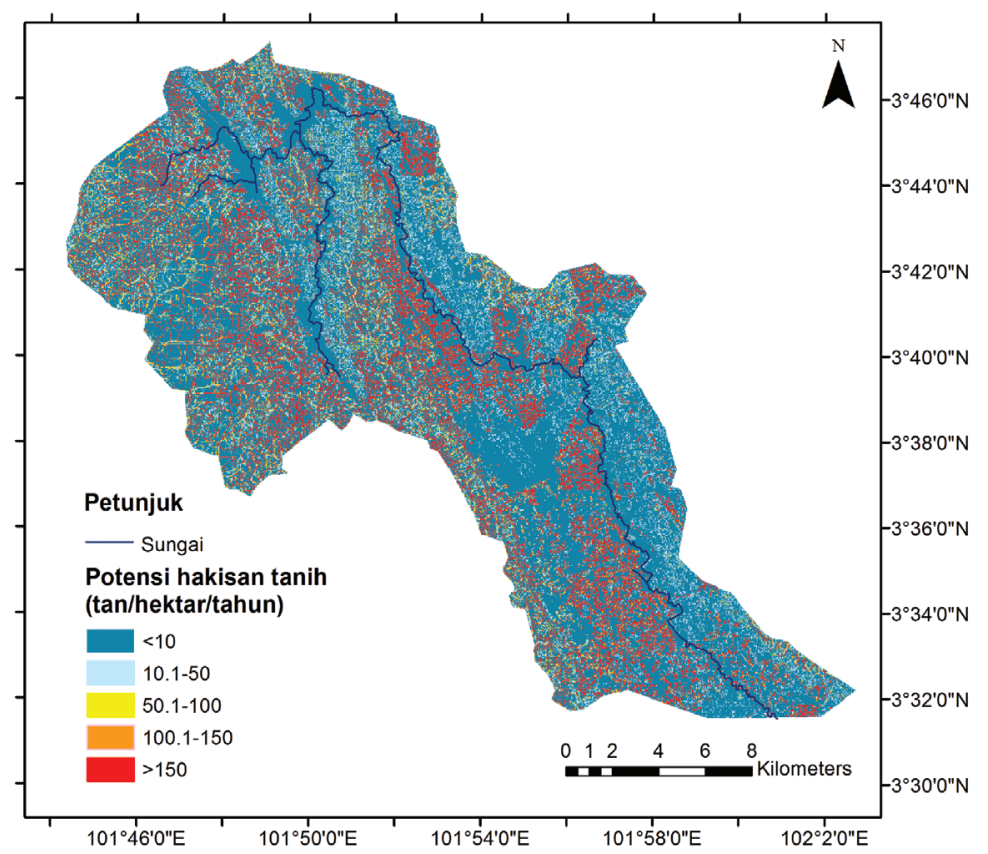

RAJAH 4. Peta potensi hakisan tanih di lembangan Sungai Bilut

kapasiti lembapan yang tinggi kerana jenis tanah tersebut mempunyai keupayaan untuk memegang air dalam masa dua hingga tiga hari selepas hujan lebat (Brandy \& Weil 2000). Kawasan kajian juga menunjukkan bahawa hakisan tanih adalah tinggi di kawasan yang mempunyai siri tanih Serdang Kedah dan Tanah Curam yang mempunyai nilai $\mathrm{K}$ pada 0.128 dan 0.500 . Siri tanih yang mempunyai nilai kebolehhakisan yang tinggi seperti siri Serdang mengandungi butiran yang kasar, agregat lemah dan kurang bahan organik. Kekurangan bahan organik akan menyebabkan tanih mempunyai ikatan zarah yang lemah, meningkatkan kebolehhakisan tanih dan meningkatkan potensi hakisan di kawasan kajian.

Beberapa lokasi persampelan di kawasan kajian mempunyai siri tanih Serdang Kedah yang mempunyai potensi hakisan tinggi. Kwi et al. (1980) menyatakan bahawa siri tanih Serdang, Rengam dan Munchong adalah tergolong dalam senarai siri tanih yang paling biasa mengalami kebolehhakisan tinggi di Malaysia. Secara keseluruhannya, sebanyak 46\% daripada kawasan kajian mempunyai tanih daripada siri Serdang, Rengam dan Munchong yang memberi kesan kepada potensi hakisan tanih di kawasan kajian. Oleh yang demikian, faktor kebolehhakisan tanih ini mempengaruhi potensi hakisan tanih secara signifikan $(r=0.83)$.

Faktor topografi juga memainkan peranan penting dalam penentuan potensi hakisan. Potensi hakisan adalah lebih tinggi di kawasan yang mempunyai nilai LS yang tinggi kerana peningkatan nilai sudut cerun dan panjang cerun boleh meningkatkan hakisan (Mitasova et al. 1996). Kawasan yang mempunyai nilai kecerunan melebihi 5\% adalah lebih cenderung mengalami hakisan tanih berbanding kawasan yang mempunyai kecerunan kurang daripada 5\%. Kawasan kajian yang mempunyai faktor LS yang tinggi iaitu mempunyai cerun curam dan panjang terutamanya di barat laut kawasan kajian menunjukkan potensi hakisan yang tinggi secara signifikan $(r=0.98)$. Air larian permukaan meningkat selari dengan peningkatan kecerunan sesuatu cerun tersebut (Troeh et al. 1991). Manakala nilai LS yang rendah mencatatkan potensi hakisan tanih pada kelas hakisan sangat rendah serta mempunyai litupan tumbuhan seperti di tenggara kawasan kajian.

Taburan tumbuhan penutup memainkan peranan yang penting dalam mengawal hakisan terutamanya hakisan yang disebabkan oleh impak titisan hujan. Kawasan kajian menunjukkan hakisan tanih yang tinggi berlaku di kawasan pertanian, bandar dan tanah lapang begitu juga di sesetengah kawasan hutan yang mempunyai nilai LS yang tinggi. Kecerunan sesuatu hakisan tanih biasanya tinggi di kawasan hutan dipterokarpa berbukit berbanding di kawasan tanah rendah (Baharuddin 1988). Potensi hakisan tanih adalah tinggi di kawasan yang mempunyai nilai $\mathrm{C}$ dan $P$ yang tinggi kerana faktor $\mathrm{C}$ dan $\mathrm{P}$ mempunyai perkaitan yang tinggi dengan potensi hakisan $\operatorname{tanih}(r=0.83 \mathrm{dan} r=$ $0.79)$.

Keputusan kajian mendapati sebanyak $74 \%$ daripada kawasan kajian mengalami hakisan yang sangat rendah, $7 \%$ adalah rendah, $4 \%$ adalah sederhana, $13 \%$ adalah tinggi dan $2 \%$ adalah sangat tinggi. Ketepatan model hakisan tanih dilakukan menggunakan ujian korelasi antara analisis ramalan kadar hakisan menggunakan GIS dan pengukuran kadar hakisan di lapangan. Ujian korelasi menunjukkan perkaitan positif yang tinggi $(r=0.81)$ antara analisis ramalan dan pengukuran hakisan tanih di kawasan kajian. Model hakisan ini menunjukkan ketepatan sebanyak $81 \%$. Berdasarkan parameter RUSLE, faktor LS, C dan K merupakan faktor utama yang mendorong 
kepada hakisan di kawasan kajian. Kawasan kajian yang mempunyai nilai LS, C dan K yang tinggi lebih berpotensi berlakunya hakisan terutamanya di barat laut kawasan kajian. Guna tanah kawasan ini terdiri daripada hutan dipterokarpa, pertanian dan kawasan lapang. Kawasan ini juga merupakan kawasan tanah tinggi iaitu terletak di bawah Bukit Fraser. Walau bagaimanapun, semua parameter RUSLE adalah saling berkait dalam menentukan hakisan di lembangan Sungai Bilut. Beskow et al. (2009) mencadangkan beberapa langkah pemuliharaan seperti membaiki sistem perparitan terutamanya bagi kawasan bandar, pembinaan teres bertingkat pada cerun, menanam tumbuhan penutup bumi terutamanya pada kawasan penanaman semula kelapa sawit dan getah dan meningkatkan lagi peratus bahan organik dalam tanah terutamanya pada kawasan kritikal yang berlaku hakisan.

\section{KESIMPULAN}

Sebahagian besar kawasan lembangan Sungai Bilut menunjukkan potensi hakisan tanih yang sangat rendah iaitu meliputi $74 \%$ daripada kawasan kajian. Kawasan lain yang mempunyai potensi hakisan tanih rendah iaitu sebanyak $7 \%$, sederhana sebanyak $4 \%$, tinggi sebanyak $13 \%$ dan $2 \%$ adalah pada kelas sangat tinggi. Faktor utama yang mempengaruhi hakisan di lembangan Sungai Bilut adalah faktor topografi, litupan tumbuhan dan kebolehhakisan tanih.

Potensi hakisan tanih di kawasan kajian boleh dikurangkan dengan perlaksanaan langkah-langkah pencegahan hakisan iaitu dengan mengurangkan pembukaan atau penerokaan tanah baru terutamanya di tempat yang berpotensi tinggi berlakunya hakisan tanih seperti di kawasan bukit yang mempunyai cerun yang curam. Manakala kawasan pertanian di lereng bukit pula disaran melakukan teres dan sistem saluran air di bahagian permukaan cerun supaya air mudah disalirkan ke dalam sistem perparitan.

\section{PENGHARGAAN}

Kajian ini dijalankan di bawah geran penyelidikan UKM (No. geran LIV-2014-04 dan LIV-2015-01). Penulis ingin mengucapkan terima kasih kepada UKM di atas anugerah geran penyelidikan tersebut serta menyediakan kemudahan peralatan dan ruang untuk menjayakan penyelidikan ini.

\section{RUJUKAN}

Abdulla, H.H. 1966. A study of development of Podzol profiles in Dovey Forest. Ph.D. Thesis, University of Wales, Aberystwyth (tidak diterbitkan).

Avery, B.W. \& Bascomb, C.L. 1982. Soil Survey Laboratory Methods. Harpenden: Soil survey Technical Monograph No. 6.

Baharuddin, K. 1988. Effect of logging on sediments yield in a hill dipterocarp forest in Peninsular Malaysia. The Journal of Tropical Forest Science 1(1): 56-66.

Beskow, S., Mello, C.R., Norton, L.D., Curi, N., Viola, M.R. \&
Avanzi, J.C. 2009. Soil erosion prediction in the Grande River Basin, Brazil using distributed modelling. Catena 79: 49-59. Brandy, N.C. \& Weil, R.R. 2000. Elements of the Nature and Properties of Soils. 2nd ed. New Jersey: Prentice Hall.

Drzewiecki, W., Wężyk, P., Pierzchalski, M. \& Szafrańska, B. 2013. Quantitative and qualitative assessment of soil erosion risk in Małopolska (Poland), supported by an object-based analysis of high-resolution satellite images. Pure and Applied Geophysics 171(6): 867-895.

Ibrahim, A.L., Lateh, H., Ismail, W.R., Weng, C.N., Hsiang-te, K. \& Pin-Shuo, L. 2002. Effects of hill land development and soil erosion on sedimentation and water resources in Malaysia. In River 99: Towards Sustainable Development, Penang. Universiti Sains Malaysia. hlm. 314-319.

Jaafar, M., Yusof, A.H. \& Yahaya, A. 2011. Analisis tahap kebolehruntuhan tanah dengan menggunakan skala ROM: Kajian di kampus Universiti Kebangsaan Malaysia, Bangi. Geografia Malaysian Journal of Society and Space 7(3): 45-55.

Jabatan Pengairan dan Saliran Malaysia. 2010. Potensi Hakisan Tanih Semenanjung Malaysia. Kuala Lumpur: Kementerian Sumber Asli dan Alam Sekitar.

Kamaludin, H., Lihan, T., Ali Rahman, Z., Mustapha, M.A., Idris, W.M.R. \& Rahim., S.A. 2013. Integration of remote sensing, RUSLE and GIS to model potential soil loss and sediment yield (SY). Hydrology and Earth System Sciences Discussion 10: 4567-4596.

Kementerian Sumber Asli dan Alam Sekitar. 2010. Preparation of Design Guides for Erosion and Sediment Control in Malaysia. Kuala Lumpur: Jabatan Pengairan dan Saliran.

Kirkby, M.J. 1980. Soil Erosion: Soil Loss Estimation. New York: John Wiley \& Sons.

Kwi, S.N.,Haridas, G., Seng, Y.C. \& Hua, T.P. 1980. Soil Erosion and Conservation in Peninsular Malaysia. Soil Erosion and Conservation in Peninsular Malaysia. Kuala Lumpur: Rubber Research Institute of Malaysia.

Mahmud, A.R., Sakawi, Z. \& Abdul Maulud, K.A. 2015. Pakej penambahbaikan EIA di Malaysia: Suatu ulasan kritis dalam aspek kawalan hakisan tanah dan sedimentasi. Journal of Society and Space 6: 23-35.

Markose, V.J. \& Jayappa, K.S. 2016. Soil loss estimation and prioritization of sub-watersheds of Kali River basin, Karnataka, India, using RUSLE and GIS. Environmental Monitoring and Assessment 188(4): 1-16.

Millward, A.A. \& Mersey, J.E. 1999. Adapting the RUSLE to model soil erosion potential in a mountainous tropical watershed. Catena 38(2): 109-129.

Mitasova, H., Hofierka, J., Zlocha, M. \& Iverson, L.R. 1996. Modelling topographic potential for erosion and deposition using GIS. International Journal of Geographical Information Systems 10(5): 629-641.

Mohamad Abd Manap, Mohammad Firuz Ramli, Wan Nor Azmin Sulaiman \& Noraini Surip. 2010. Application of remote sensing in the identification of the geological terrain features in Cameron Highlands, Malaysia. Sains Malaysiana 39(1): 1-11.

Morgan, R.P.C. 2005. Soil Erosion and Conservation. Edisi ke-3. UK: Blackwell.

Muhammad Rendana, Sahibin Abdul Rahim, Wan Mohd Razi Idris, Tukimat Lihan \& Zulfahmi Ali Rahman. 2017. Soil erosion assessment in Tasik Chini catchment using remote sensing and GIS techniques. Sains Malaysiana 46(4): 529535 . 
M. Hamid, C.H., M., Ashraf, Qudsia Hamid, Syed Mansoor Sarwar \& Zulfiqar Ahmad Saqib. 2017. Geospatial techniques for assessment of bank erosion and accretion in the Marala Alexandria Reach of the River Chenab, Pakistan. Sains Malaysiana 46(3): 413-420.

NRCS - USDA State Office of Michigan. 2002. Technical Guide to RUSLE use in Michigan.

Panagos, P., Meusburger, K., Ballabio, C., Borrelli, P. \& Alewell, C. 2014. Soil erodibility in Europe: A high-resolution dataset based on LUCAS. Science of the Total Environment 479-480: 189-200

Qing, X.Y., Mei, S.X., Bin, K.X., Jian, P. \& Long, C.Y. 2007. Adapting the RUSLE and GIS to model soil erosion risk in a mountains karst watershed, Guizhou Province, China. Journal of Environmental Monitoring and Assessment 141(1): 275-286.

Renard, K.G., Foster, G.R., Weesies, G.A., McCool, D.K. \& Yooder,D.C. 1997. Predicting Soil Erosion by Water: A Guide to Conservation Planning with the Revised Soil Loss Equation (RUSLE). Washington: US Department of Agriculture.

Terrence, J.T., George, R.F. \& Kenneth, G.R. 2002. Soil Erosion: Processes, Prediction, Measurement, and Control. United States: John Wiley \& Sons.
Troeh, F.R., Hobbs, A.J. \& Donahue, R.L. 1991. Soil and Water Conservation. 2nded. Englewood Cliffs, N.J.: Prentice-Hall Incorporation.

Troeh, F.R., Hobbs, A.J. \& Donahue, R.L. 1999. Soil and Water Conservation: Productivity and Environment Protection. New Jersey: Prentice - Hall.

Wischmeier, W.H. \& Smith, D.D. 1978. Predicting Rainfall Erosion Losses: A Guide to Conservation Planning. Washington: US Department of Agriculture.

Pusat Pengajian Sains Sekitaran dan Sumber Alam

Fakulti Sains dan Teknologi

Universiti Kebangsaan Malaysia

46300 UKM Bangi, Selangor Darul Ehsan

Malaysia

*Pengarang untuk surat-menyurat; email: matt@ukm.my

Diserahkan: 31 Mac 2018

Diterima: 8 Jun 2018 